\title{
Immunopathological Evaluation of Protective Potential of Cajanus indicus on Aflatoxin Induced Toxicity in Broilers
}

\author{
N. Sahu ${ }^{1}$, M. Mondal ${ }^{2 *}$, R.C. Ghosh ${ }^{1}$ and Shonam Tamrakar ${ }^{1}$ \\ ${ }^{1}$ Department of Veterinary Pathology, College of Veterinary Science and Animal Husbandry, \\ Chhattisgarh Kamdhenu Vishwavidyalaya, Durg, Chhattisgarh, India \\ ${ }^{2}$ Department of Veterinary Clinical Complex, F/O-Veterinary and Animal Sciences, West \\ Bengal University of Animal and Fishery Sciences, Kolkata, India \\ *Corresponding author
}

\begin{abstract}
A B S T R A C T
The aim of the present study was to elucidate the protective potential of herb, Cajanus indicus on aflatoxin (AF) induced immunopathological alterations in commercial broilers.

Keywords

Broiler, Immunopathology, Aflatoxicosis

Article Info

Accepted:

10 August 2018

Available Online:

10 September 2018

A total of 168 Vencobb day old broiler chicks were randomly divided into four equal groups of 42 each. Group I broilers were given plain feed and served as control whereas, group II and III were given Cajanus indicus leaf powder (CLP) @ 2 g/kg and AF @ 1 ppm with normal feed respectively. Group IV broilers were fed on diet containing AF @ 1 ppm and CLP @ $2 \mathrm{~g} / \mathrm{kg}$ for 42 days. The results revealed a significant $(\mathrm{P} \leq 0.01)$ increase in skin thickness in the control groups I and II at 24 and $48 \mathrm{hrs}$ post challenge (1\% Dinitroflurobenzene in vehicle) as compared to intoxicated groups III and IV. AF toxicity significantly reduced the development of humoral immune response in broilers and supplementation of $C$. indicus could partially protect the reduction in HA titers of AF intoxicated broilers. Aflatoxicosis significantly suppressed the both cell mediated and humoral immune responses. But CLP supplementation had a potent immunomodulatory effect. So, it helps not only in controlling aflatoxicosis but also can play a pivotal role in correcting chicken immune dysfunction.
\end{abstract}

\section{Introduction}

Poultry industry is designated as most dynamic and fastest growing segment amongst agricultural and livestock sectors in India. In comparison to agriculture and other livestock farming, poultry now-a-day serves as an income stabilizer and provides a regular and lucrative income to farmers. High quality nutrition is a primary requirement for healthy poultry birds in excellent condition with optimal production levels. Recently the feed production technology has paid a good deal of attention for all extrinsic and intrinsic quality factors.

However, feed safety is a concern for achieving the optimum productivity and consumer confidence. Aflatoxin (AF) is a collective term for a group of extremely toxic and carcinogenic secondary metabolites produced by some strains of Aspergillus flavus 
and Aspergillus parasiticus during their growth on feeds and foods is a major concern for the poultry production. Aflatoxins are potent carcinogens and cause heavy economic losses in poultry due to growth depression, poor feed conversion efficiency, carcass yield and carcass quality and reduced disease resistance (Bedre et al., 2010). Aflatoxin, the most common hepatotoxin, can cause impairment of humoral and cellular immune responses and increase susceptibility to some environmental and infectious agents (Ibrahim et al., 2000; Oguz et al., 2003). Eminent researchers and producers aim to develop effective prevention, management and decontamination technologies to minimize the toxic effects of AF. Previously, the adsorbent based studies have been conducted to remove AF from contaminated feed to minimize the toxicity of AF in poultry ${ }^{2}$. Recently there has been a growing interest in establishing the therapeutic potentials of plants and plant derived molecule for the drug development.

A nontoxic edible herb, Cajanus indicus (Kundu et al., 2008) locally available in India is one of those plants which have many folk medicinal uses. A $43 \mathrm{kDA}$ protein isolated from Cajanus indicus has recently been demonstrated to have efficient hepatoprotective effect (Kundu et al., 2008; Sarkar et al., 2005; Manna et al., 2007). In view of the above medicinal properties, the present study is designed to investigate the ameliorative activity of Cajanus indicus against induced aflatoxicosis in broilers.

\section{Materials and Methods}

\section{Production of aflatoxin}

The AF was produced from Aspergillus flavus NRRL - 18079 pure culture (Institute of Microbial Technology, Chandigarh, India) via fermentation of rice by the method of Shotwell et al., (1966). Fermented rice was then steamed to kill the fungus, dried and ground to fine crystalline powder. Hundred grams of powder from the culture substrate sample was sent to Animal Feed Analytical and Quality Control Laboratory, Veterinary College, Namakkal, Tamilnadu, India for quantification of $\mathrm{AF}$. The $\mathrm{AF}$ within the rice powder consisted of $165 \mathrm{ppm} \mathrm{AFB}_{1}, 28 \mathrm{ppm}$ $\mathrm{AFB}_{2}$ and $20 \mathrm{ppm} \mathrm{AFB}_{2}$. The rice powder was added to the basal diet to provide the required amount of $1 \mathrm{ppm}\left(1 \mathrm{mg} \mathrm{kg}^{-1}\right)$.

\section{Collection and preparation of the plant material}

Leaves of Cajanus indicus were collected and botanically identified. The mature leaves of Cajanus indicus was shade dried and reduced to fine powder using electric grinder and the powder was stored in airtight containers.

\section{Chickens and diet}

The experimental investigation was planned for immunopathological evaluation of protective potential of Cajanus indicus on Aflatoxin induced toxicity in broilers after obtaining approval from Institutional Animal Ethics Committee. Clinically healthy one hundred and sixty eight one-day-old, Cobb400 broiler chicks of both sexes, weighing 48$50 \mathrm{~g}$ were obtained from a commercial hatchery and were reared on deep litter system of housing using rice husk with provision of artificial light at night.

The chicks were fed a standard commercial feed starter upto14 days, thereafter a grower diet upto 28 days and finisher upto 42 days. Chickens were allowed access to the diets and fresh and clean drinking water ad libitum. The basal diets were tested for possible residual AF before feeding and there were no detectable levels present. All the experimental chicks were kept under close observation during entire period of study. 


\section{Experimental Design}

Individually weighed chicks were randomly divided into 4 groups of 42 chicks; each group consisting of 3 replicates of 14 chicks. The experimental design consisted of four dietary treatments: 1. Control: Basal diet; 2. Basal diet $+2 \mathrm{~g} \mathrm{CLP} \mathrm{kg}^{-1}$ diet; 3. Basal diet + $1 \mathrm{ppm}$ AF; 4. Basal diet $+1 \mathrm{ppm} \mathrm{AF}+2 \mathrm{~g} \mathrm{CLP} \mathrm{kg}^{-1}$ diet. When the chicks reached 42 days of age, the feeding trial was terminated.

\section{Cell mediated immunity (CMI)}

Cell mediated immune response was measured by Di Nitro Fluro Benzene (DNFB) test as described by Phanuphak et al., (1974) and later slightly modified by Tamang et al., (1988). Featherless area was marked on both sides of abdomen and cleaned thoroughly with acetone and air dried. Right lateral side of abdomen was used for DNFB application whereas left side served as control. 2000 $\mu \mathrm{g}$ of DNFB in $0.1 \mathrm{ml}$ of acetone and olive oil (4:1) was applied on the right marked area on the abdomen using a plastic ring to avoid spillage. The sensitized birds were challenged with $50 \mu \mathrm{g}$ of DNFB in $0.1 \mathrm{ml}$ of acetone and olive oil $(4: 1)$ on the same area on $14^{\text {th }}$ day after initial sensitization. The response to DNFB was assessed by measuring the skin thickness using engineer's micrometer on 0,24 and 48 hours of post challenge with three readings each and the overall mean skin thickness was calculated.

\section{Humoral immunity}

Humoral immune response was assessed by micro haemagglutination test according to the method of Thaxton et al., (1974). HA plates were thoroughly dried and cleaned. Sheep blood was collected in equal volume of Alsever's solution and allowed to stabilize for one week. Sheep RBC's obtained after centrifugation was washed thrice in normal saline solution (NSS) and finally a 7\% suspension of SRBC was prepared. For immunization $1 \mathrm{ml}$ of this suspension was injected intravenously in six birds from each group and the birds were bled on 10 days following injection. Blood was allowed to clot at $37^{\circ} \mathrm{C}$ for few hours and refrigerated. Serum was collected and heated in a water bath to inactivate the complement fraction. The antibody production due to immunization was assessed by micro haemagglutination test. The reciprocal of the highest dilution of serum that caused complete haemagglutination was considered as HA titre and expressed as $\log _{2}$ values.

\section{Results and Discussion}

The mean skin thicknesses of broilers in different groups have been given in Table 1 . The cell mediated immune response in vivo in broilers was estimated by chemical contact sensitization with DNFB. The skin reaction of broilers challenged with DNFB includes swelling, erythema, oedema, vesiculation, scab formation and sloughing. Overall skin reaction was more pronounced at 24 hours than 48 hours post challenges. The present study revealed a significant $(\mathrm{P} \leq 0.01)$ increase in skin thickness in the control groups I and II at 24 and $48 \mathrm{hrs}$ post challenge as compared to intoxicated groups III and IV which indicate immunosuppression in terms of cellular immunity during aflatoxicosis. However, induced aflatoxicosis significantly suppressed the cell mediated immune response of broilers in both periods of post challenge in comparison to control. CLP supplemented birds of group IV showed better CMI status than the respective control groups, although the difference was insignificant statistically. The results on humoral immune status of broilers were summarized in Table 2. The AF treated broilers (group III) exhibited a highly significant $(\mathrm{p} \leq 0.01)$ decrease in HA titer as compared to groups. 
Table.1 DNFB response (mean increase in skin thickness in $\mathrm{mm}$ ) of broiler chicks exposed to aflatoxin and $C$. indicus (Left side served as vehicle control and right side treated with the

DNFB) $(n=6)$

\begin{tabular}{|c|c|c|c|c|}
\hline \multirow{2}{*}{ Groups } & $\begin{array}{c}\text { Abdominal } \\
\text { side }\end{array}$ & $\begin{array}{c}\text { Before } \\
\text { sensitivation }\end{array}$ & \multicolumn{2}{|c|}{ After sensitivation } \\
\hline \multirow{2}{*}{ Gr I } & Left & $0.55 \pm 0.01$ & $\mathbf{2 4} \mathbf{~ h r}$ & $\mathbf{4 8 ~ h r}$ \\
& Right & $0.55 \pm 0.02^{\mathrm{a}}$ & $3.58 \pm 0.03^{\mathrm{a}}$ & $0.55 \pm 0.01$ \\
\hline \multirow{2}{*}{ Gr II } & Left & $0.56 \pm 0.01$ & $0.6 \pm 0.02$ & $3.51 \pm 0.03^{\mathrm{a}}$ \\
\hline \multirow{2}{*}{ Gr III } & Right & $0.58 \pm 0.03^{\mathrm{a}}$ & $3.52 \pm 0.13^{\mathrm{a}}$ & $3.40 \pm 0.12^{\mathrm{a}}$ \\
\hline & Left & $0.56 \pm 0.02$ & $0.57 \pm 0.13$ & $0.56 \pm 0.01$ \\
\hline \multirow{2}{*}{ Gr IV } & Right & $0.57 \pm 0.02^{\mathrm{a}}$ & $2.32 \pm 0.06^{\mathrm{b}}$ & $2.20 \pm 0.07^{\mathrm{c}}$ \\
\hline & Left & $0.66 \pm 0.02$ & $0.67 \pm 0.02$ & $0.62 \pm 0.03$ \\
\hline Level of & Right & $0.61 \pm 0.02^{\mathrm{a}}$ & $2.52 \pm 0.06^{\mathrm{b}}$ & $2.44 \pm 0.07^{\mathrm{b}}$ \\
\hline significance & & $\mathrm{NS}$ & $* *$ & $* *$ \\
\hline
\end{tabular}

Table.2 Effects of $C$. indicus supplementation on haemagglutination titres of Aflatoxin treated broilers $(n=6)$

\begin{tabular}{|l|c|c|c|c|c|}
\hline & Group I & Group II & Group III & Group IV & $\begin{array}{c}\text { Level of } \\
\text { significance }\end{array}$ \\
\hline $\begin{array}{l}\text { HA Titre } \\
\text { (log } 2 \text { values) }\end{array}$ & $5.05 \pm 0.12^{\mathrm{a}}$ & $5.27 \pm 0.30^{\mathrm{a}}$ & $3.4 \pm 0.21^{\mathrm{c}}$ & $4.22 \pm 0.18^{\mathrm{b}}$ & $* *$ \\
\hline
\end{tabular}

However, broilers of group IV had significantly higher HA titer than group III. It indicates that AF toxicity significantly reduced the development of humoral immune response in broilers and supplementation of C. indicus could partially protect the reduction in $\mathrm{HA}$ titers of $\mathrm{AF}$ intoxicated broilers.

Values indicate Mean \pm S.E., Superscript may read column wise for mean comparison. Similar superscript showing means do not differ significantly. $\left({ }^{*} \mathrm{P} \leq 0.05, * * \mathrm{P} \leq 0.01\right)$

Presently induced aflatoxicosis significantly reduced CMI response to DNFB of broilers in both periods of post challenge in comparison to control. Previously Shivchandra et al., (2003) observed reduced CMI response to DNCB in AF treated broilers. A similar decreased CMI response was recorded by Bakshi et al., (1998) and Sawale et al., (2009) in AF induced broilers and ochratoxin induced layers, respectively. A significant decrease in CMI response of the present study might be attributed due to the adverse effect on chemotactic and phagocytic action of lymphocytes (Ghosh et al., 1991). However, birds of group IV revealed better CMI status as compared to group III which might be due to the immunomodulatory effect of $C$. indicus (Datta et al., 1999).

The present findings of reduced humoral immune response due to aflatoxicosis and partial protection in reduction of HA titers due to supplementation of $C$. indicus were in accordance with those of Kurkure et al., (Kurkure et al., 2000) who observed reduced immune response of broilers during 
aflatoxicosis. Reduced immune response recorded in the present study could be accounted for decreased protein and globulin synthesis, impaired processing of antigen due to depressed phagocytosis during aflatoxicosis in broilers and direct lymphotoxic activity of mycotoxin (Kalorey et al., 2005). In the present study, lymphocytolysis of lymphoid organs might be responsible for reduced HA titers. So, it can be concluded that aflatoxin @ 1ppm caused significant immunosuppression and broilers may experience mortality due to secondary infection resulting from $\mathrm{AF}$ induced immunosuppression. However, supplementation of $C$. indicus revealed significant improvement of immune status of the broilers and provided a moderate amelioration in AF toxicity.

\section{References}

Bakshi CS, Sikdar A, Johri BTS, Malik M. 1998. Effect of graded levels of aflatoxin on cell mediated immune response in broilers. Indian $J$ Comparative Microbiol Immunol Infectious Diseases 19: 40-42.

Bedre DK, Kulkarni GB, Gangane GR, Mote CS, Dhaygude VS. 2010. Efficacy of 'Toxiroak' (herbal preparation) on gross and histopathological observations in mycotoxicosis in broilers. Indian $J$ Vet Pathol 34: 141-144.

Datta S, Sinha S, Bhattacharyya P. 1999. Effect of a herbal protein, CI-1, isolated from Cajanus indicus on immune response of control and stressed mice. $J$. Ethnopharmacol., 67: 259-267.

Ghosh RC, Chauhan HVS, Jha GJ. 1991. Suppression of cell- medicated immunity by purified aflatoxin $\mathrm{B}_{1}$ in broiler chicks. Vet Immunol Immonopathol., 28:165-172.

Ibrahim IK, Shareef AM, Al-Joubory KMT. 2000. Ameliorative effects of sodium bentonite on phagocytosis and Newcastle disease antibody formation in broiler chickens during aflatoxicosis. Res Vet Sci., 69: 119-122.

Kalorey DR, Kurkure NV, Ramgaonkar JS, Sakhare PS, Warke S, Nigot NK. 2005. Effect of polyherbal feed supplementation "Growell" during aflatoxicosis, ochratoxicosis and combined mycotoxicosis in broilers. Asian-Australion J Animal Sci., 18(3): 375- 383.

Kundu R, Dasgupta S, Biswas A, Bhattacharya A, Pal BC, Bandyopadhyay D, Bhattacharya S. 2008. Cajanus cajan Linn. (Leguminosae) prevents alcoholinduced rat liver damage and augments cytoprotective function. $J$ Ethnopharmacol., 118: 440-447.

Kurkure NV, Pawar SP, Kognole SM, Gaonorkar AG, Bhandarker AG, Kalorey DR. 2000. Amerliorative effect by turmeric (Curcuma longa) in induced aflatoxicosis in cockerels. Indian J Vet Pathol., 24: 26-28.

Manna P, Sinha M, Sil PC. 2007. Galactosamine-induced hepatotoxic effect and hepatoprotective role of a protein isolated from the herb Cajanus indicus $\mathrm{L}$ in vivo. Biochem MolecularToxicol 21: 13-23.

Oguz H, Hadimli HH, Kurtoglu V, Erganis O. 2003. Evaluation of humoral immunity of broilers during chronic aflatoxin (50 and $100 \mathrm{ppb}$ ) and clinoptilolite exposure. Revue de Medicine Veterinaire., 154: 483-486.

Phanuphak P, Moorhead JW, Claman HN. 1974. Tolerance and contact sensitivity to DNFB in mice. In vivo detection by ear swelling and correlation with in vitro cell stimulation. J Immunol., 112: 115-123.

Sarkar K, Ghosh A, Sil PC. 2005. Preventive and curative role of a $43 \mathrm{kD}$ protein 
from the leaves of the herb Cajanus indicus $\mathrm{L}$ on thioacetamide-induced hepatotoxicity in vivo. Hepatol Res., 33: 39-49.

Sawale GK, Ghosh RC, Ravikanth K, Maini S, Rekhe DS. 2009. Experimental mycotoxicosis in layer induced by ochratoxin $\mathrm{A}$ and its amelioration with herbomineral toxin binder 'toxiroak'. International J Poultry Sci., 8: 798-803. Shivachandra SB, Sah RI, Singh SD, Johri TS, Manimaran K. 2003. Pathobiochemical and immunological changes in experimental aflatoxicosis. Indian J Poultry Sci., 38: 137-141.
Shotwell OL, Hesseltine CW, Stubblefield RD, Sorenson WG. 1966. Production of aflatoxin on rice. Applied Microbiol., 14: 425-428.

Tamang RK, Jha GJ, Gupta MK, Chauhan HVS, Tiwari BK. 1988. In vivo immunosuppression by synthetic pyrethroid (cypermethrin) in mice and goats. Vet Immunol Immunopathol., 19: 299-305.

Thaxton JP, Tung HT, Hamilton PB. 1974. Immunosuppression in chickens by Aflatoxin. Poultry Sci., 53: 721-725.

\section{How to cite this article:}

Sahu, N., M. Mondal, R.C. Ghosh and Shonam Tamrakar. 2018. Immunopathological Evaluation of Protective Potential of Cajanus indicus on Aflatoxin Induced Toxicity in Broilers. Int.J.Curr.Microbiol.App.Sci. 7(09): 1637-1642.

doi: https://doi.org/10.20546/ijcmas.2018.709.197 